\title{
Editorial
}

\section{Sete vezes Mises}

\section{Adriano de C. Paranaiba}

Neste primeiro número de 2019, se dá a abertura do sétimo volume do periódico MISES: Revista Interdisciplinar de Filosofia, Direito e Economia. Isso representa o início do sétimo ano de publicações ininterruptas deste importante veículo de difusão das ideias da Escola Austríaca de Economia, tanto no Brasil, como no mundo.

Pesa sobre nós uma grande responsabilidade de iniciar esse ano com extremo êxito, especialmente dado o significado do número sete, que indiscutivelmente é o número mais admirado, e misterioso, na ciência, religião, filosofia e literatura, desde os tempos mais remotos da humanidade, até os dias atuais. Na tradição judaica Shamayim é a morada de Deus, estrutura formada por sete céus. A Bíblia cita o número sete 323 vezes, e diversas outras religiões também dão forte e místico significado para esse número. Pitágoras remete o número sete a algo poderoso, perfeito e sagrado. Platão irá no Livro VII, do diálogo República, discutir a natureza dos números. Nesta ocasião, ele próprio, Platão, indica o número sete como origem da alma do mundo. De forma similar, Hipócrates, tido como o pai da medicina, considerava o número sete como o motor da vida e fonte das mudanças.

Sete são as notas musicais, os dias da semana, as cores do arco-íris e até mesmo as glândulas endócrinas no corpo humano. A cada sete anos, iniciamos um novo ciclo da vida do homem na Terra. Neste mesmo sentido, seria justo refletir: estaremos nesta edição iniciando um novo ciclo do periódico MISES: Revista Interdisciplinar de Filosofia, Direito e Economia? Por que não acreditar que sim? Não apenas como editor-chefe, mas também como pesquisador de nossa relevante temática, acredito na verdade desta afirmação. Vejo sim um novo ciclo se desabrochar, visto que finalizamos o ano de 2018 com um processo de grandes mudanças editoriais. Entre elas, a criação de uma nova plataforma que permite acesso e gestão dos artigos em todas as etapas editoriais; indexação em diversos repositórios de periódicos científicos nacionais e

* Mini-biografia. email: Adriano de C. Paranaiba é economista. Doutor em Transportes pela Universidade de Brasília (UNB). Editor-chefe da MISES: Revista Interdisciplinar de Filosofia, Direito e Economia, bem como da sua versão on-line MISES: Interdiscplinary Journal of Philososphy, Law and Economics. Email: paranaiba@mises.org.br 
internacionais; ampliação da publicação em outros idiomas além do português, dentre outras pequenas mudanças que fazem grandes diferenças no fluxo editorial. Tais transformações, com certeza, pendem para colocar nossa revista em um novo patamar de êxitos e desafios.

Isocronicamente, a primeira seção deste fascículo possui sete artigos de pesquisa. $\mathrm{O}$ primeiro é o artigo de autoria do professor Lucas Freire, laureado pelo Prêmio Michael Novak 2018, cujo trabalho nos brinda com uma reflexão epistemológica sobre a praxiologia e sua aplicação à filosofia da ciência. Na sequencia, três artigos da área de Direito abordam a perspectiva austríaca em diversas áreas: Maria Brizola O. Silva e Dorival Guimarães Pereira Júnior analisam a evolução do conceito teórico e das práticas que envolvem a Segurança Humana, primeiramente no âmbito mundial, e posteriormente voltam a ênfase ao Brasil. A seguir, Lucas Augusto Gaioski Pagani busca demonstrar a essencialidade do Direito de Propriedade para as mais variadas sociedades em razão de seu papel como potencializador do desenvolvimento econômico, político e social. Thiago Guterres analisa a influência da Escola Histórica do Direito, mais especificamente a de seu principal representante, Friedrich Karl von Savigny, no pensamento de alguns dos principais teóricos da Escola Austríaca de Economia.

Seguindo a seção, Lucas Fiuza faz uma proposta inovadora de aplicação do Bitcoin na política monetária brasileira. Thiago Castro Sousa apresenta os efeitos da competição institucional como processo de aprendizado social incentivador de desenvolvimento socioeconômico e limitador do poder político. Fechando a seção, Lucas Souto Ribeiro nos escreve em espanhol sobre a deterioração da economia venezuelana.

A seção seguinte desta edição, Ensaios \& Insights, possui três artigos publicados. No primeiro, os autores Rodrigo Braian Nori, Marcel Pereira Bernardo e Leandro Garcia Meyer, em um estudo bibliográfico, investigam algumas contribuições à teoria econômica feitas pelos principais economistas da Escola Austríaca, desde seus precursores, com os escolásticos de Salamanca, até os aportes de F. A. Hayek. Em seu artigo escrito em inglês, Patrick Reimers discute os argumentos e ideias de Guido Hülsmann e Margaret Moore sobre o direito de secessão. João Daniel Ruettimann fecha a seção com uma brilhante leitura sobre os problemas no setor de saúde suplementar de saúde brasileira, derivados das políticas intervencionistas estabelecidas pelas agências reguladoras.

Arrematando a edição, dois excelentes livros foram resenhados. O autor português João Pinheiro Silva apresenta a edição, também portuguesa, do livro "Impostores e Incendiários Os Pensadores da Nova Esquerda" de Roger Scruton. Por fim, mas não menos importante, Luís Felipe Junqueira de Andrade apresenta o livro “O Estado de Direito: Constitucionalismo, democracia e o futuro da nação", escrito por José Stelle, um dos mais importantes precursores do liberalismo no Brasil.

O que anseio a partir daqui é que essa seleção de artigos possa abrilhantar o início deste ano e contribuir com o crescimento da pesquisa científica da Escola Austríaca de Economia. Encerro esse editorial acreditando que os artigos publicados possam ser como sementes em seu ciclo de vida. $\mathrm{O}$ semeador, que aqui pode ser representado pelos autores dos artigos, ao produzir seu estudo e publicá-lo, pode sentir-se cansado após o árduo trabalho, e talvez até mesmo desanimado por não ver o resultado imediato de seus esforços. Contudo, ainda que o semeador não compreenda ou veja, a semente germina e cresce mesmo longe de seus olhos, movida pelo empenho do cultivo feito. Esta, em seu próprio tempo, brota, faz surgir a planta, 
impulsiona a flor, fortalece a espiga. Desta forma, a semente se multiplica e todo processo faz florir, frutificar e florescer. Que a produção científica deste periódico possa multiplicar as ideias de L. V. Mises, que possa frutificar compreensões, florescer novas descobertas e olhares, e quem sabe, florir mais o mundo a nossa volta, para que cada dia mais, maior seja o número de ideias iluminando a escuridão. 